\title{
CAUSAS E OBJETIVOS DA REVOLUÇÃO DE $\left.1932{ }^{\star}\right)$.
}

O assunto é mais complexo do que se supõe. Não é possível estudar a Revolução de 1932, sem estudar antes a RevoIução de 1930, pois ambas formam um só todo, um só drama em dois atos.

A Revolução de 1930 projeta raizes num passado distante, que vai a rigor até a proclamação da República em 1889. Todavia, podemos, abandonando as causas mais remotas, partir da campanha hermista em 1910. O jornal "O Estado de São Paulo" fixou bem êsse aspecto da questão na nota que abaixo transcrevemos (1):

"Em nossa longa carreira profissional, assistimos a inúmeras crises. A primeira delas se iniciara com os tiros do Forte de Copacabana sôbre o Ministério da Guerra. E êles anunciavam à Nação a abertura de um ciclo nôvo da sua História. Pouco tempo antes, calara-se para sempre a mais alta voz da consciência cívica nacional: Ruy Barbosa deixara de fazer-se ouvir no Parlamento, nos comícios, nas praças públicas. $E$ fôra êsse o sinal para que se abrisse o período marcado pelos levantes militares. Durante a sua longa e admirável carreira política, contivera o grande tribuno os ímpetos militaristas do nosso Exército, e foi mesmo um dos seus maiores feitos o ter impedido que a candidatura Hermes da Fonseca, imposta pela fôrça representada na figura do caudilho Pinheiro Machado, se transformasse numa ditadura.

Ao levante de 5 de julho de 1922, suceder-se-ia, em 1923, a revolta libertadora no Rio Grande do Sul. Esta significava o protesto de uma facção do povo gaúcho contra a ditadura que sôbre aquêle Estado exercia, sem contraste e durante vinte anos, o sr. Borges de Medeiros. Um

\footnotetext{
(*). - Resumo da comunicação feita pelo autor na Sociedade de Estudos Historicos em sessão de 31-X-1961. Completando esta nota e em comemoração ao 30.0 aniversário da Revolução Constitucionalista de 1932, a-Revista de História estampa a seguir uma bibliografia, a mais completa possível, sôbre o assunto (Nota da Redação).

(1). - Edição de 26-10-1961.
} 
ano mais tarde, tocaria a São Paulo a vez de assistir ao levante da Fôrça Pública e da quase totalidade das fôrças da II Região Militar, sob o comandlo do então coronel Isidoro Dias Lopes. Obrigados a retirar-se do nosso Estado, os revolucionários se bifurcaram, indo parte dêles para Mato Grosso e os demais para o Paraná. Fazendo a junção neste Estado, formariam os remanescentes do levante de São Paulo a Coluna Prestes, de legendária memória.

A situação continuou a agravar-se dia a dia, pela incrível falta de visão com que se havia à frente do govêrno a oligarquia que desde os primórdios da República dominava o País. Em conseqüência, us políticos profissionais da época abriram o caminho para a revolução que os haveria, em 1930, de varrer do cenário político nacional. Entrávamos no apogeu do periodo revolucionário aberto a 5 de julho de 1922 pelos "Dezoito do Forte" nas areias da Copacabana".

Para que a síntese acima, da pena de Júlio Mesquita Filho, fôsse perfeita, seria preciso conter o papel da Liga Nacionalista, fundada por lentes e alunos das escolas superiores de São Paulo, estimulados pelas pregações cívicas dos tribunos Rui Barbosa e Olavo Bilac. Essa instituição foi mandada fechar pelo presidente Artur Bernardes, após o malôgro da Revolução de 1924 .

Fechada a Liga Nacionalista, renasceu de suas cinzas, ou melhor, do seu espírito, em 1926, o Partido Democrático, do qual foi primeiro presidente o nonagenário Antônio Prado, ex-senador do Império. Perfilhando o programa da Liga, bateu-se o Partido Democrático valentemente pela renovação do Brasil, adotando e realizando um regime constitucional compatível com o adiantamento e os desejos da Nação, e que tivesse por base, entre outras conquistas, o voto secreto, a justiça eleitoral, a representação, e porfiando ainda pela melhoria das condições de vida das classes menos favorecidas.

O Partido Democrático pregou no deserto. Continuaram a desordem administrativa e a corrupção eleitoral. O Partido Democrático, dando a mão a outros partidos congêneres do Sul, Norte e Centro, tornou-se um dos membros da Aliança Liberal, cujo programa reproduzia os itens acima enunciados.

Sobrevindo a sucessão de Washington Luís, o Partido Democrático bateu-se contra o candidato Júlio Prestes impôsto pelo Presidente, sem audiência da Nação, aceitando a candidatura Getúlio Vargas, com o compromisso dêste de adotar o programa da Aliança Liberal. 
Júlio Prestes saiu eleito presidente da República na eleição de $1 .^{\circ}$ de março de 1930 . Mas êsse pleito, onde também se escolheram os representantes federais (deputados e senadores), decorreu debaixo da mais deslavada fraude, em todo o Brasil, mas sublimada em São Paulo, na presença de observadores, jornalistas e políticos, adrede enviados dos demais Estados da Federação.

Diante dêsse descalabro sem remédio, o. Partido Democrático, acompanhando a Aliança Liberal, passou a conspirar contra o govêrno de Washington Luís.

Além da corrupção eleitoral, super-organizada em $10^{\circ}$ de março de 1930, Washington Luís, assenhoreando-se da maioria da Câmara Federal, arrancou dela a depuração das bancadas de oposição de Minas Gerais e Paraíba e, numa incompreensível justiça de dois pesos e duas medidas, respeitou a bancada do Rio Grande do Sul...

Somem-se a êsse fator próximo, outras duas importantes concausas da Revolução de 1930:

a) a crise econômica do café, que podia ser atenuada por providências governamentais;

b) o clima internacional, dado o espírito de imitação do brasileiro ou o contágio de movimentos revolucionários vitoriosos na Argentina, no Chile, etc...

Triunfante a Revolução de 1930, em que o Partido Democrático tomou parte ativa mais na pregação do que na luta armada, guindou-se ao govêrno da República o presidente do Rio Grande do Sul, Getúlio Vargas.

Mas êste, logo de início, deixou de cumprir os compromissos assumidos com o Partido Democrático, que indicara para governador de São Paulo o presidente da agremiação: Professor Francisco Morato.

Mesmo assim, concordou o Partido Democrático em fazer parte do secretariado em tôrno de um jovem militar - o Capitão João Alberto, que se comprometeu, em documento formal, executar apenas as deliberações dêsse gabinete, do qual faziam parte as figuras de J. M. Whitaker, Plínio Barreto, Vicente Rao, J. C. Macedo Soares, Souza Queirós, Monlevade e Cardoso de Melo Neto.

Getúlio Vargas, revelando a intenção de continuar no govêrno discricionàriamente, deixou à margem o programa da Aliança Liberal e, ao invés de tirar São Paulo das mãos inábeis e estranhas de João Alberto (êste confessaria em suas Memórias a sua incapacidade), entregando-o a um paulista e 
civil, nomeou aquêle militar interventor e aprovou-lhe $o$ ato de insubordinação ao seu gabinete.

Essas traições de um e de outro personagem, levaram o Partido Democrático, num gesto admirável, a abandonar imediatamente tôdas as posições administrativas ocupadas e a romper, em célebre manifesto, com João Alberto (2) .

O Partido Democrático não se limitou a êsse rompimento: passou da palavra à ação. Vários dos seus próceres aliaramse ao General Isidoro Dias Lopes (sempre ao lado de São Paulo), comandante da II Região Militar, e com vários dos melhores elementos da Fôrça Pública, desfechando assim contra João Alberto e seu Secretário da Segurança - General Miguel Costa - o movimento de 28 de abril de 1931, que infelizmente malogrou.

Todo o ano de 1931 foi das maiores provações para o Partido Democrático, fiador de Getúlio Vargass junto à desolada população de São Paulo, embora nomeasse êle para o Estado um interventor civil e paulista - Laudo de Camargo - logo depois acintosamente demitido.

Ao findar-se êsse triste ano de 1931, o Partido Democrático, cansado de pleitear e aguardar em luta insana que o ditador voltasse dos seus erros e felonias, rompeu oficial e violentamente com êste (3).

Em seguida, em nobilíssimo impulso recíproco, as duas velhas comunhões - o Partido Democrático e o Partido Republicano Paulista - que pareciam inimigos irreconciliáveis, juntaram-se numa "frente única" memorável para a defesa de São Paulo, bem como para alcançar a reconstitucionalização do País, na base do programa da Aliança Liberal.

A essa "frente única" aderem as mais importantes associações de classe do Estado e organizam-se instituições diferentes de civis, com o mesmo escopo, salientando-se entre elas ligas de senhoras paulistas.

Fruto imediato dessa união sagrada foi a nomeação do diplomata aposentado Pedro de Toledo para interventor em São Paulo. Estava Getúlio Vargas certo da compassividade de seu delegado, mas enganou-se. Pedro de Toledo, como bom paulista procurou servir não a Getúlio Vargas e seus tenentes do "Clube 3 de outubro", mas à terra do seu nascimento.

(2). - Aureliano Leite, Memórias de um revolucionárici. São Paulo, 1931.

(3). - Vide manifesto de 3 de janeiro de 1932, in Aureliano Leite, Martírio e Glória de São Paulo. São Paulo, 1934. 
A população de São Paulo, ganhando alento, começou a se manifestar por todos os meios contra a Ditadura, dando fôrça: e prestígio à "frente única", já em confabulações com o Exército e a Fôrça Pública. Sucedem-se comícios monstros, indes-critíveis, pregando a revolução.

Nos dias 22 e 23 de maio a manifestação das ruas da Carpital atinge o máximo quando o povo teve conhecimento de que Getúlio Vargas mandara o seu ministro Osvaldo Aranha depor Pedro de Toledo. Houve lutas mortíferas nas vias públicas, culminando na Praça da República, onde em combate com a: Legião Revolucionária, tombaram quatro moços paulistas: Martins, Miragaia, Dráusio e Camargo.

$\mathrm{Na}$ última noite o povo, guiado por vários tribunos, - entre êles Ibraim Nobre -, vai ao Palácico dos Campos Elísios e exige a substituição do secretariado, suspeito de getulismo, por um nôvo secretariado oriundo da "frente única". Dêsse se-cretariado faziam parte Waldemar Ferreira, P. de Morais Barros, Fonseca Teles, Tirso Martins, Rodrigues Alves, Gofredo. Teles, F. Junqueira e J. Sampaio Vidal.

Funda-se na noite seguinte, no Clube Comercial, a associação secreta M. M. D. C. (que adotou como sigla as iniciais dos: quatro moços tombados na Praça da República), que prestou relevantes serviços na fase conspiratória e que seria mais tar-. de oficializada pelo govêrno revolucionário.

Passa-se a conspirar a portas abertas. Realizados os últimos ajustamentos, as últimas combinações, o desfêcho foi an-. tecipado de alguns dias. Ocorreu êste nos últimos minutos dá: noite de 9 de julho, na Chácara do Carvalho, para onde o Coronel Manuel Rabelo, então comandante da II Região Militar, havia mudado - por motivos táticos - a sede do seu comando. Tomam parte nesse histórico episódio, além do Coronel Euclides de Figueiredo - , chefe interino do setor militar do movimento na ausência dos Generais Isidoro Dias Lopes e Bertoldo Klinger -, outros militares e os civis Júlio de Mesquita. Filho, - um dos maiorais da Revolução - Carlos Nazaré, Eu-. rico de Souza Leão, Leopoldo Figueiredo, Edgar Batista Pereira, Roberto Moreira, Sílvio de Campos, Marcos Mélega, Carlos: Sá, Tito Pacheco, Bernardo de Morais, Alvaro Macedo e além. do Autor, outros naturalmente esquecidos, como infelizmente. sempre acontece.

Eis, afinal, a Revolução de 1932. Teve por objetivos: além. de entregar São Paulo a si mesmo, obrigar a Ditadura a recolocar a Revolução no seu verdadeiro caminho, obedecendo às. 
reivindicações da Aliança Liberal, como o disse João Neves da Fontoura (4).

Não foi, pois, a Revolução de 1932 um movimento separatista, conforme a Ditadura assoalhava e ùltimamente, lastimosamente, afirmaram o ex-chanceler Afonso Arinos (5) e a filha do ditador, Alzira Vargas (6). Dizem o contrário dessas declarações:

a) O brazão de armas de São Paulo, adotado em 29 de agôsto de 1932, quando a Revolução se considerava vitoriosa, brazão que se assenta na divisa: Pro Brasilia fiant eximia;

b) a bandeira da Aviação Constitucionalista, tìpicamente nacionalista (7);

c) os chefes militares, $98 \%$ de outros Estados;

d) os nomes de batalhões sempre de outros Estados;

e) o manifesto distribuído no Rio de Janeiro, assinado pelas principais figuras não políticas de São Paulo, atestando o caráter nacionalista do movimento.

A Revolução de 1932 não foi também a contra-Revolução de 1930. Provam-no, além de outros argumentos:

a) o manifesto da "frente única" assinado pelo próprio Partido Republicano Paulista;

b) carta íntima de Júlio Prestes, escrita da Europa a seu filho Fernando, declarando que voltava ao Brasil, via Buenos Aires, a fim de tentar passar para as hostes que lutavam contra a Ditadura, sem. existir nêle qualquer intenção reivindicatória. Queria lutar como simples soldado para conseguir que o Brasil voltasse a ter uma constituição. Júlio Prestes não chegou a entrar no Brasil, sendo aconselhado a voltar para a Europa, de Buenos Aires, a fim de evitar complicações com o seu gesto.

A Revolução de 1932, um dos mais belos movimentos armados de todos os tempos, não conseguiu alcançar uma vitória material, mas acabou conseguindo o seu fim indiretamente com .a Constituição de 1934. Quanto às causas do seu malôgro, caberiam elas em outra comunicação a ser feita.

\section{AURELIANO LEITE}

\footnotetext{
(4). - João Neves da Fontoura, Acuso. Rio de Janeiro, 1934, pág. 209.

(5). - Afonso Arinos, Um parlamentar da República.

(6). - Alzira Vargas do Amaral Peixoto, Meu Pai, Rio de Janeiro, 1960.

(7). - Clovis Ribeiro, Brazóes e Bandeiras do Brasil, São Paulo, 1933.
} 
De bine, "Parnex"," 1-1x-932.

Fenams,

De Livenper, no dia de mon mithy

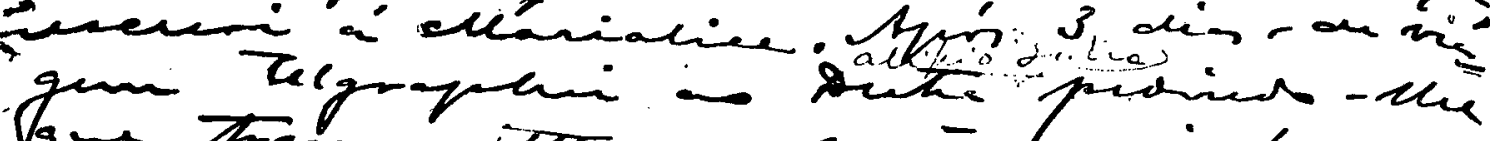

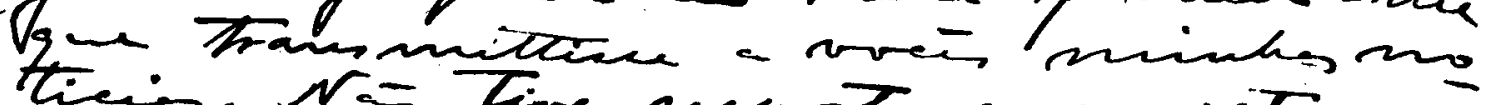

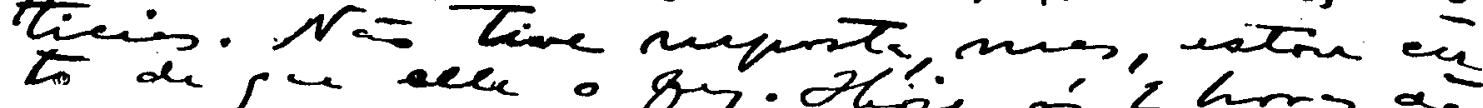

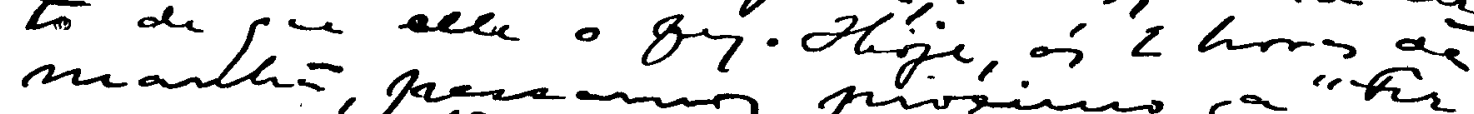

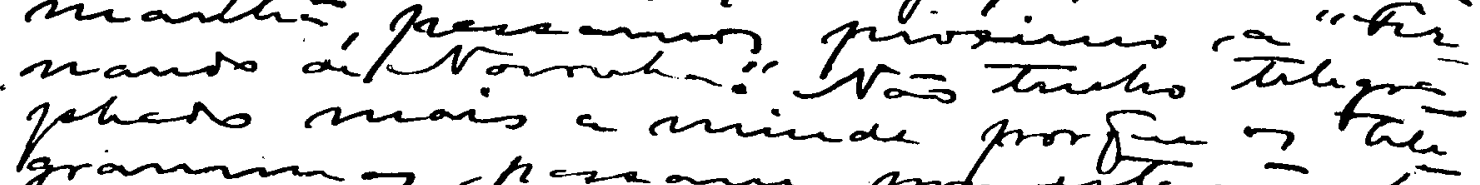

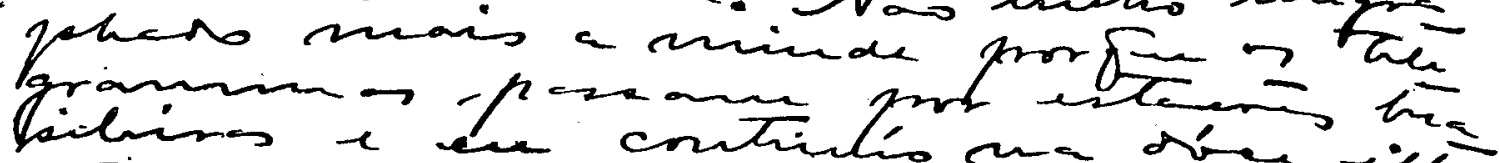

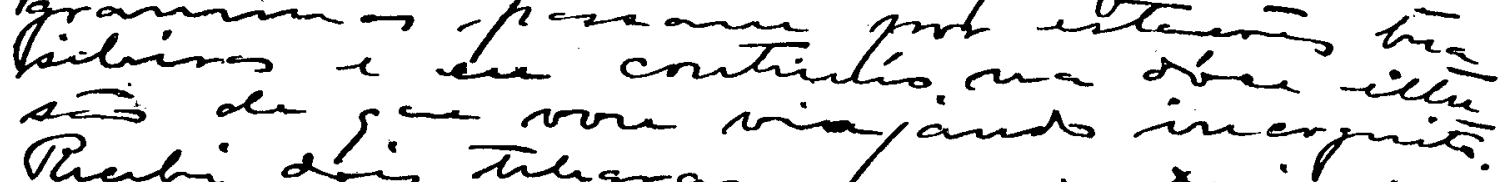

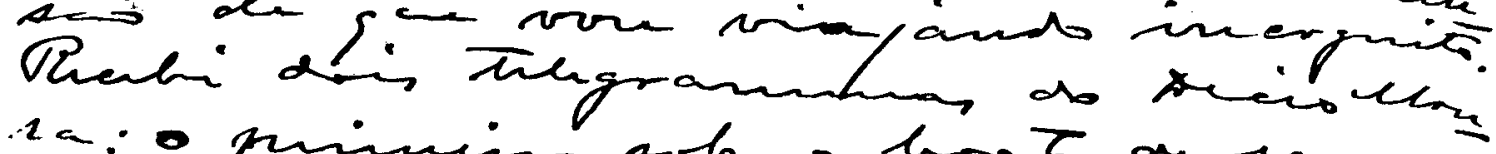

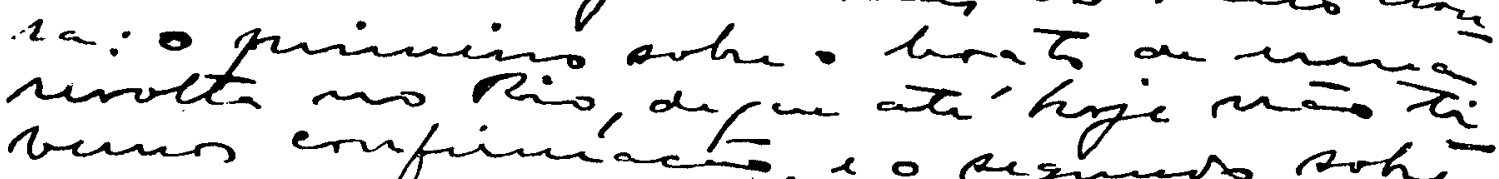

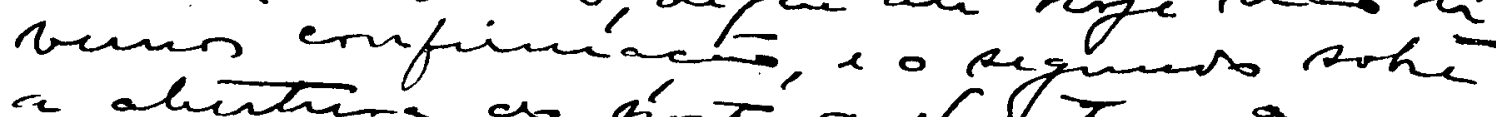

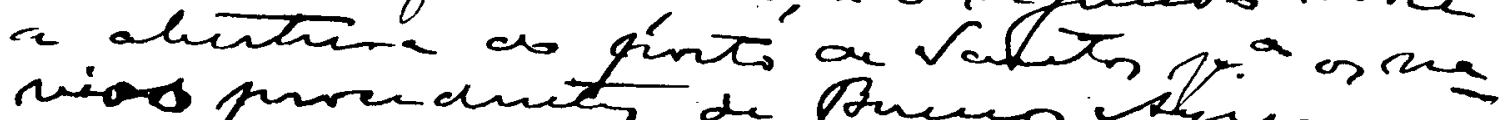

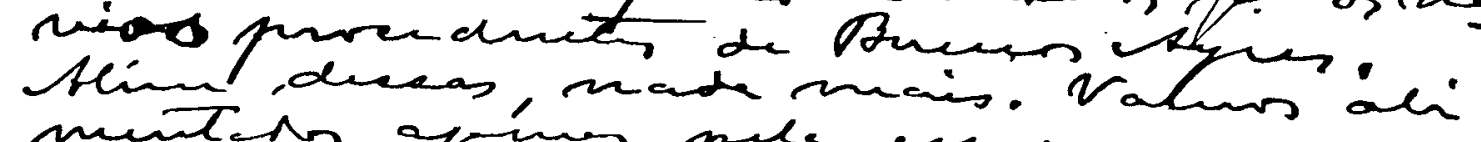

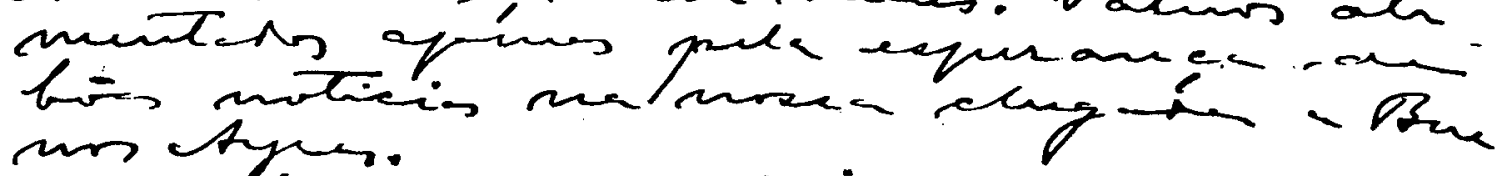
ming Ays.

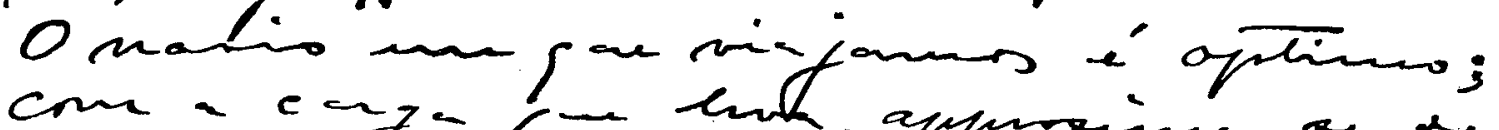

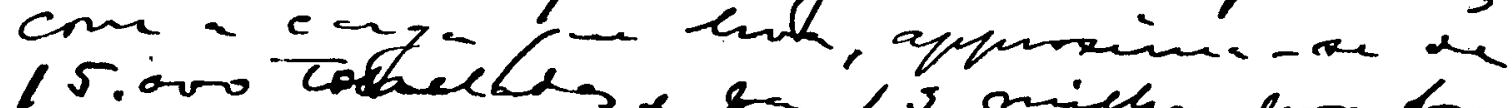

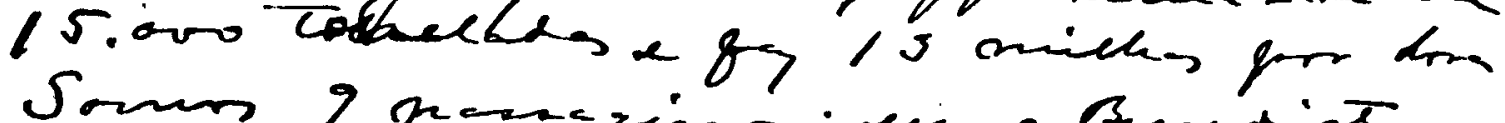
Soun 7 perayins: en, o Bundid e

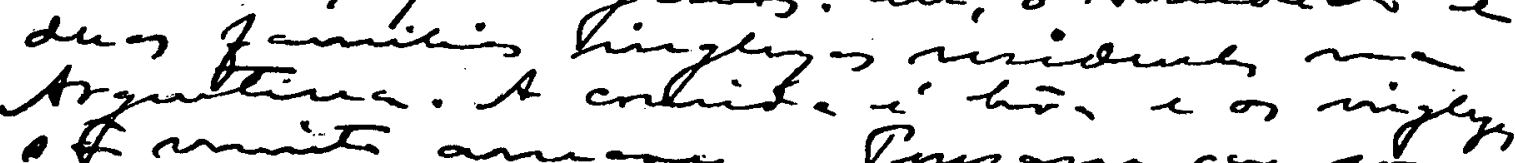

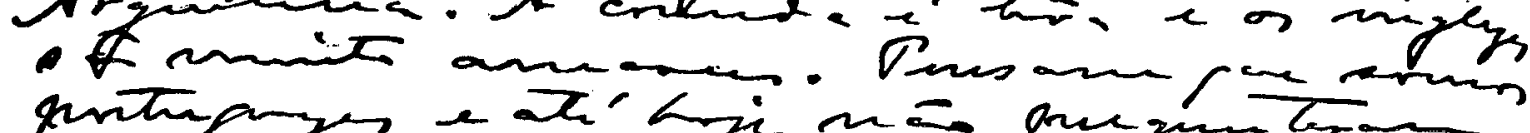

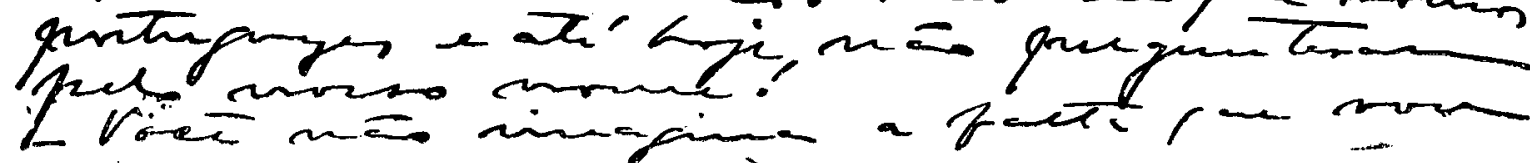




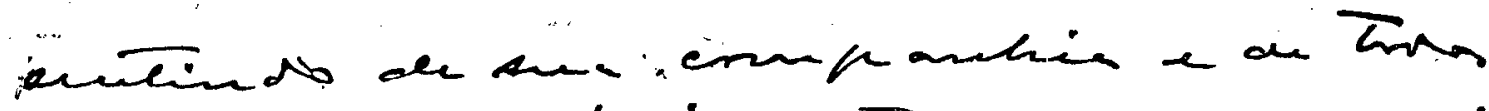

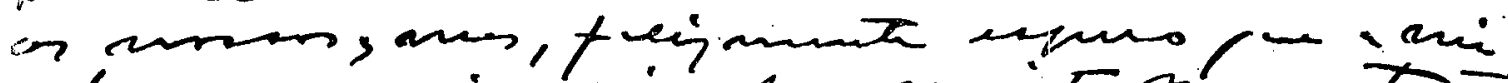

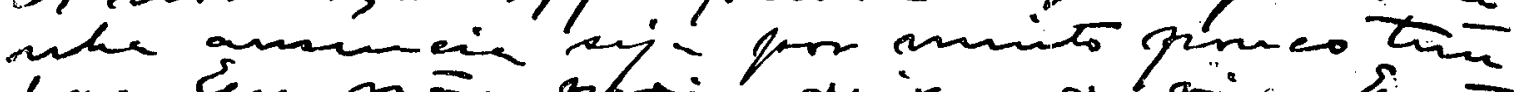

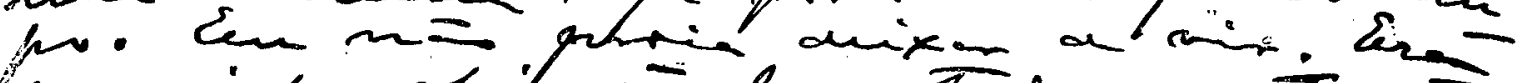

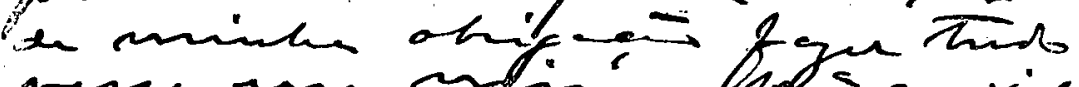

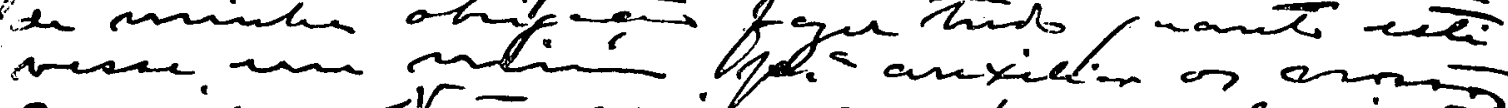

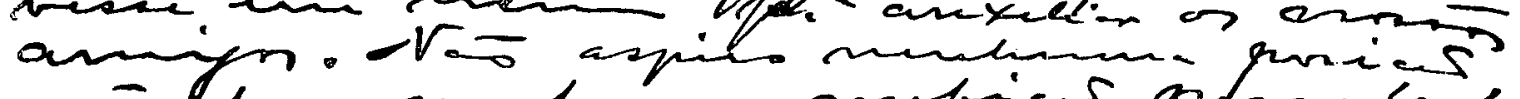

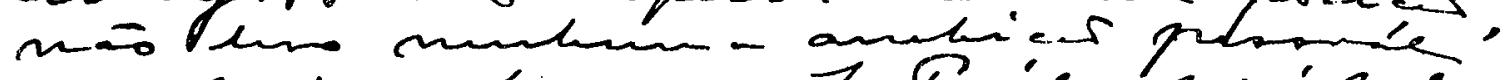

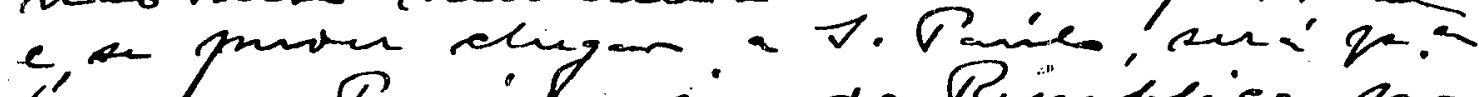

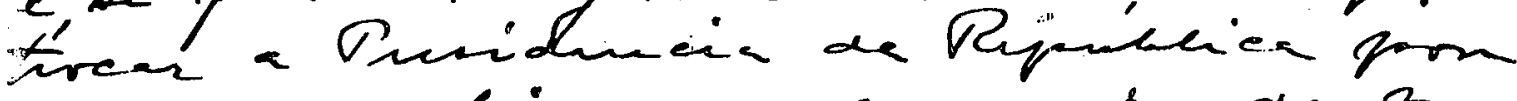

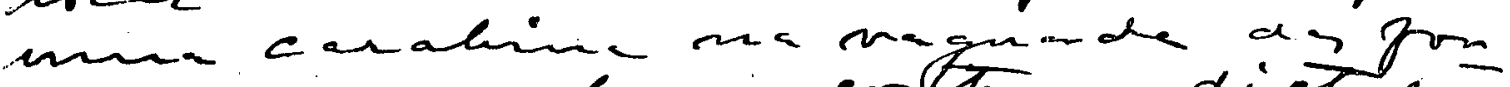

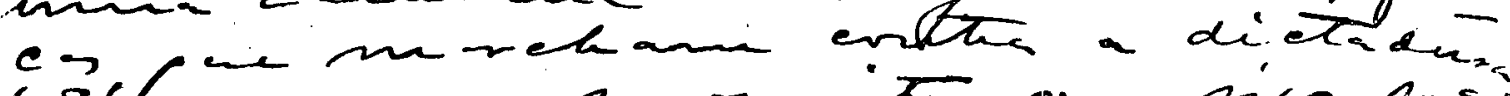

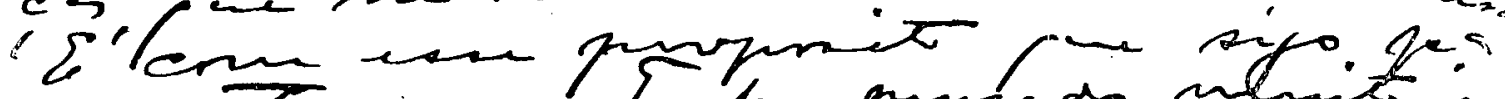

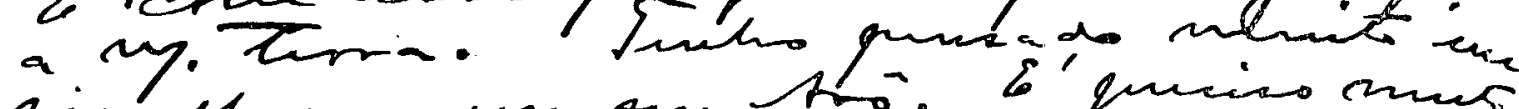

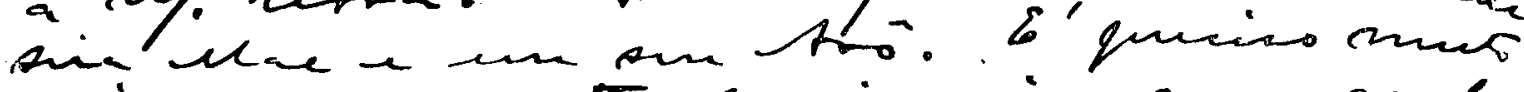

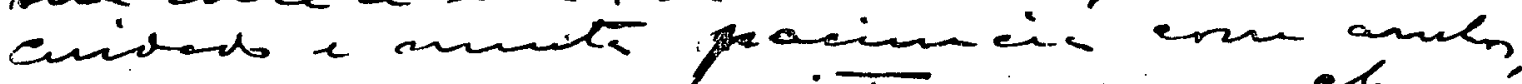

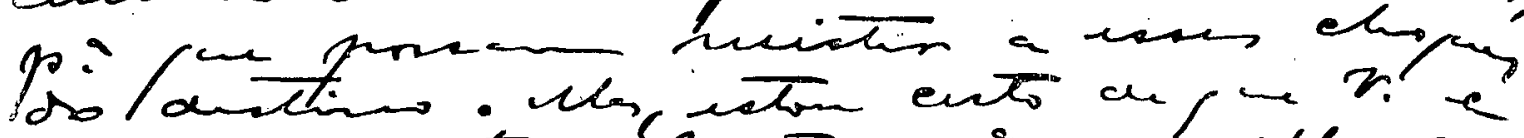

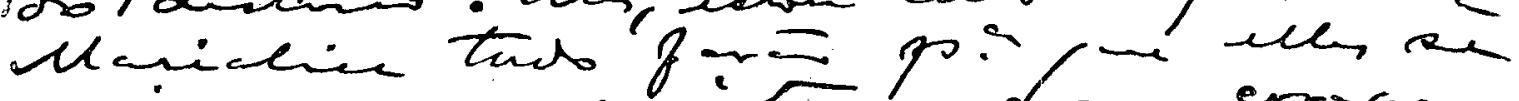

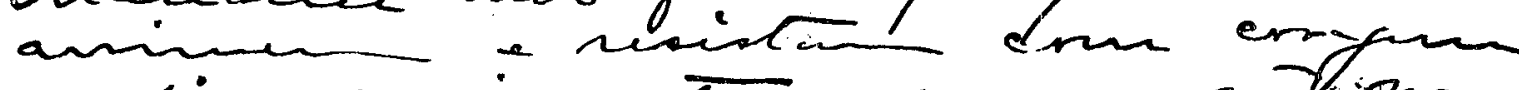

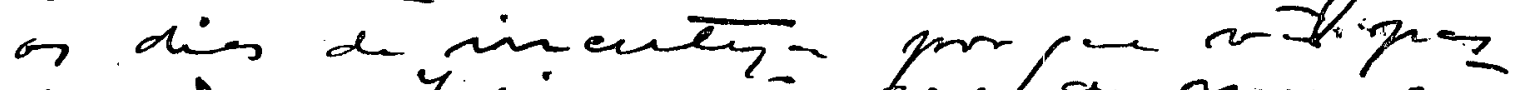

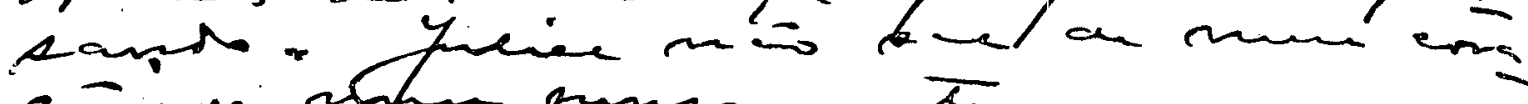

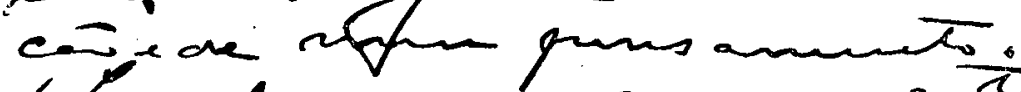

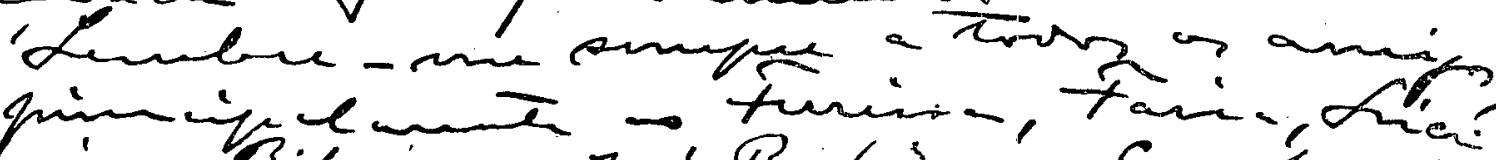

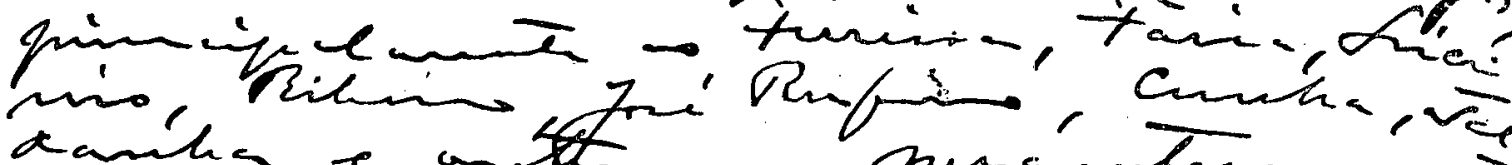

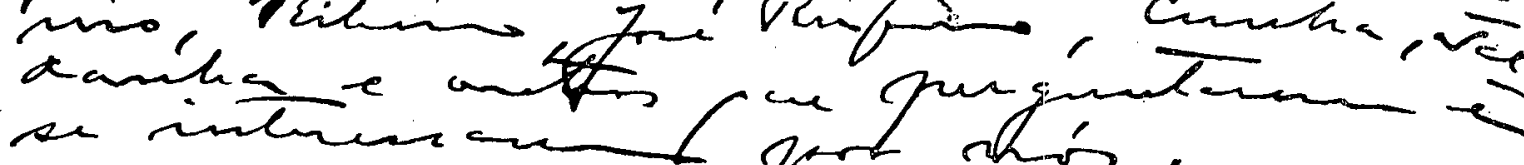

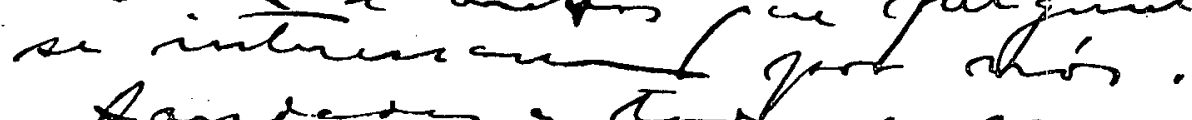

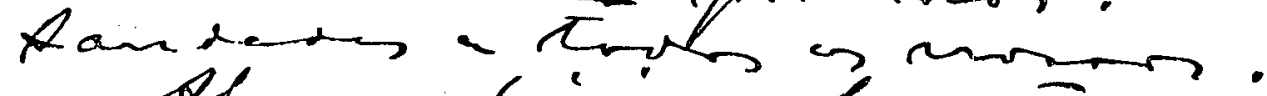

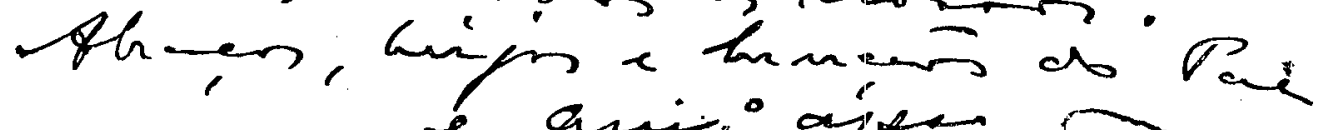
e amin ajp.

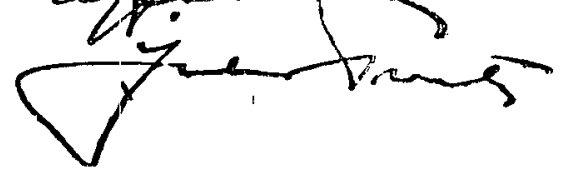

